In the TS and $C$ groups the starch content in the small intestine, caecum and large intestine varied between 0.5 and $1.5 \mathrm{~g}$; in the $\mathrm{S}$ group it varied between 10 and $19 \mathrm{~g}$. The high intestinal starch content in the $\mathrm{S}$ group was accompanied by a reduced $\mathrm{pH}$ mainly in the caecum and in the large intestine.

Although the intestine of $S$ kids contained more starch than that of TS ones, heattreated starch stimulated higher apparent amylase secretion than raw starch. Trypsin activity was higher in the pancreas and small intestine of the $S$ and $C$ groups than in their $M$ and TS counterparts. This could be due to the higher consumption of soybean protein.

The adaptive capacity of the intestine to digest and absorb starch is limited in kids, therefore, the amount of starch that can be included in a liquid dict should be quantified accordingly.

The daily body gain was $232,226,202$ and $175 \mathrm{~g}$ in groups $\mathrm{M}, \mathrm{TS}, \mathrm{S}$ and $\mathrm{C}$, respectively. The final body weight which was attained after $65,65,73$ and $76 \mathrm{~d}$ was 19.6, 19.3, 19.5 and $18.2 \mathrm{~kg}$ for the respective groups.

The utilization of dry matter, protein and energy was significantly lower in S and $\mathrm{C}$ groups than in $\mathrm{M}$ and TS ones. Feed/Gain ratios were $1.35,1.40,1.72$ and 2.09 in $\mathrm{M}$, TS, $\mathrm{S}$ and $\mathrm{C}$ groups, respectively.

Body fat - around kidneys and along the gastrointestinal tract (GIT) - was related to the amount of milk replacer consumed, so was the carcass grade. The weight of the kidneys and GIT fat was $986,759,620$ and $298 \mathrm{~g}$ for M, TS, S and C groups, respectively. The carcass grade (according to veal calves, when $1=$ white and $4=$ red) was $1,2,3,3.2$ in the respective groups.

When maximal growth is required in order to reach market weight in the shortest period, feeding liquid diets is recommended, the substitution of part of the milk replacer by starch-soy mixture may be economical.

Key words : Milk replacer, soybean, starch, kid, gastrointestinal tract.

\title{
Effects of nutritional factors, castration and weight at slaughter on fattening of male kids
}

\author{
P. MORAND-FEHR, P. BAS, J. HERVIEU
}

Station de Nutrition et Alimentation (I.N.R.A.) de II.N.A. P.G. 16, rue Claute-Bernard, 75231 Paris Cedex 05

Kid carcasses have a lower fat content than those of other ruminants (Morand-FeHR et al., 1976), but their commercial value is improved by increasing their fattening score (MORAND-FEHR et al., 1980). In two experiments, we tried to improve the fattening of kid carcasses by increasing live weight at slaughter or fat content of milk substitute, by using goat milk or by castration.

In experiment I, two types of milk containing 18 and 23 p. 100 fat were given to 36 male Alpine kids slaughtered at $8-9,14-15$ and $20-21 \mathrm{~kg}$ live weight. Increase in live weight at slaughter improved the fattening scores of carcasses $(3.83,4.12,4.45)$ respectively and the weight of adipose tissues (Omentum : $67.5 \mathrm{~g}, 253.1 \mathrm{~g}, 459.3 \mathrm{~g}$; Perirenal fat : $89.8 \mathrm{~g}, 189.0 \mathrm{~g}, 288.1 \mathrm{~g}$ respectively). The high fat milk substitute did not significantly increase the fattening score of carcasses. The weight of omental adipose tissue was significantly higher with the high fat milk substitute at $14 \mathrm{~kg}(268.8 \mathrm{~g}$ vs $237.3 \mathrm{~g})$ and $20 \mathrm{~kg}$ live weight $(487.2 \mathrm{~g}$ vs $431.3 \mathrm{~g})$. The perirenal tissue showed the same trend but not significantly.

In experiment II, goat milk or a milk substitute containing 22 p. 100 fat were given to 24 kids which were slaughtered at $14-16 \mathrm{~kg}$ live weight. Two other groups, one composed of entire male kids and the other of castrated kids were given the same milk substitute and slaughtered at $20-22 \mathrm{~kg}$ live weight. The fattening score was improved with goat milk 
(4.2 vs 3.4 with milk substitute) especially because of an increased weight of perirenal adipose tissue $(245 \mathrm{~g}$ vs $174 \mathrm{~g})$. Castration of kids increased the fattening score of their carcasses (4.31 vs 3.94 for intact kids) and the weight of adipose tissues (mesenteric fat $346 \mathrm{~g}$ vs $296 \mathrm{~g}$, perirenal fat $352 \mathrm{~g}$ vs $341 \mathrm{~g}$ ) except omental tissue.

Increase in live weight at slaughter was the most efficient factor to improve fattening of kid carcasses. Goat milk and castration could also be used to improve fattening of kids, but castration markedly reduced growth rate (ADG $228 \mathrm{~g} / \mathrm{d}$ vs $272 \mathrm{~g} / \mathrm{d}$ for intact kids). Increasing the fat content of milk substitute had a slightly favourable effect, appearing relatively late in omental and perirenal tissue.

Key words : Kid fattening, kid carcass, milk substitute, castration, goat milk, weight at slaughter.

\title{
The effect of suckling type on the pre-and postweaning lactation performance of Damascus goats and the growth rate of the kids
}

\author{
M. HADJIPANAYIOTOU \\ Agricultural Research Institute, Nicosia, Cyprus
}

Fourty-nine goats were randomly allocated at 2 days post-kiclding to double (DS), single (SS) and no-suckling (OS) treatments. Artificially reared kids were given either ewemilk (Provilamb : 25.8 p. 100 fat, 24.2 p. 100 protein) or calfmilk (Provifok: 15 p. 100 fat, 22.5 p. 100 protein) replacer. The ewe and calfmilk replacers were reconstituted in the ratio of 1 part powder to 5 or 4 parts of water, respectively.

Separation of kids from their dams reduced milk yield to weaning (DS 182, SS 179, OS $121 \mathrm{~kg} /$ goat) and from weaning (56 days postkidding) to 90 days post-partum (DS 102 , SS 90 , OS $72 \mathrm{~kg} /$ goat). There was no significant difference in milk yield between DS and SS goats. Milk sold till weaning was significantly more abundant in OS and SS goats (DS 63, SS 109 , OS $121 \mathrm{~kg} /$ goat). Milk sold from weaning to 90 days was similar in SS and DS goats, but lower in OS ones. Live weight changes between goats were not significant (DS 0.044 ; SS 0.09 ; OS $0.023 \mathrm{~kg} /$ goat/day). DS goats consumed more concentrate mixture than SS or OS ones (DS 2.13 , SS 2.08 , OS $1.85 \mathrm{~kg} /$ goat/day).

Suckling kids reared with their dams as singles were heavier at weaning $(14.6 \mathrm{~kg})$ than twins $(12.7 \mathrm{~kg})$. They were also heavier than kids born as single or twins and reared artificially in a kid-bar on calf milk replacer $(12.7 \mathrm{~kg})$. Twin suckled kids, however, were not significantly heavier than those reared artificially in a kid-bar on cow or ewemilk replacer $(13.4 \mathrm{~kg})$, although 4 kids reared on calf milk replacer died during the rearing period and their data were cxcluded from the analysis. Differences between kids reared artificially on ewemilk replacer and single suckled kids were not significant.

It may be concluded that SS of goats did not reduce milk yieid compared to DS : SS increased marketable milk and artificially reared kids grew satisfactorily.

Key words : Suckling type, goat, milk, artificial rearing, kids. 